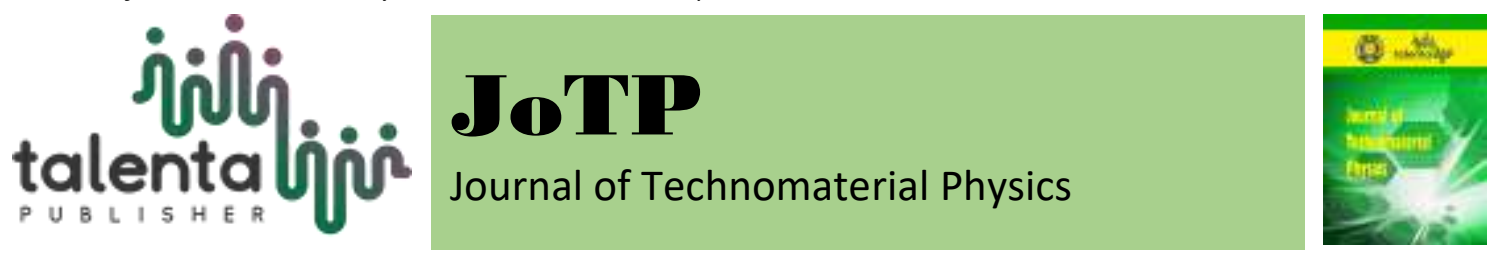

\title{
A Study of Strength Activity Index of Pozzolan and Silica Sand with Ordinary Portland Cement Using ASTM C595 / C595M-12 Method
}

\author{
Nova Susanti ${ }^{1}$, Selvia Musnicha Sari ${ }^{2}$ and Febri Maulana ${ }^{3}$ \\ ${ }^{1,2,3}$ Department of Physics, Faculty of Science and Technology, University of Jambi
}

\begin{abstract}
Strength Activity Index (SAI) is a method that aims to see the quality of additional materials mixed into the cement. The additional materials examined in this study were pozzolan from Lubuk Alung, pozzolan from Sicincin, and silica sand from Payakumbuh. This study refers to the ASTM C595/C595M-12 standard. The process started with placing specimens and mold (on a base plate) in a humid room or closet and protecting the surface from water droplets. After the mold was removed from the humid room or closet, the cubes were removed from the mold. The cubes were placed in suitable metal or glass containers, and the containers were sealed and stored at a temperature of $38.0 \pm 2.00 \mathrm{C}$ for 27 days. The specimens were cooled to $23.0 \pm 2.00 \mathrm{C}$ before the tests were carried out. The compressive strength results of pozzolan from Lubuk Alung, pozzolan from Sicincin, and silica sand from Payakumbuh were $327 \mathrm{~kg} / \mathrm{cm}^{2}, 296 \mathrm{~kg} / \mathrm{cm}^{2}$ and 199 $\mathrm{kg} / \mathrm{cm}^{2}$ respectively. Thus, the specimens which fulfilled the SAI requirement according to ASTM C-618 were pozzolan from Lubuk Alung and pozzolan from Sicincin with 91.34\% and $82.68 \%$, respectively. In contrast, silica sand from Payakumbuh did not fulfill the requirement of ASTM C-618 at a minimum of $75 \%$ because the result obtained was only $55.58 \%$.
\end{abstract}

Keyword: ASTM C595/C595M-12, Pozzolan, Silica Sand

Received 12 Mei 2019|Revised [23 August 2019] | Accepted [31 August 2019]

\section{INTRODUCTION}

The development of infrastructures in developing countries, such as Indonesia, has experienced rapid progress in the construction of buildings, houses or other constructions. In addition to the completion target of the constructions, infrastructures require good quality and durable raw materials. One of the main and important raw materials in building infrastructures is cement. Cement acts as the basic material in the construction of buildings. Furthermore, materials used in making cement will affect the quality of cement [1-4].

\footnotetext{
*Corresponding author at: Jl. Jambi-Ma. Bulian KM 15 Mendalo Darat Jambi 36361 Indonesia

E-mail address: nova_fisikaunja@unja.ac.id
} 
The production of cement in Indonesia is one of the export commodities, especially for Southeast Asia. An alternative binder is, therefore, necessary for structural and non-structural buildings [5-7]. In order to produce reliable and good quality cement at an international level, producers should be able to meet the values of international testing standards. One of the internationally recognized testing standards is ASTM (American Standard for Testing Materials). There are several sections in ASTM, one of which is ASTM C595/C595M-12 regarding Activity Index with Portland Cement [8]. The Activity Index with Portland Cement is a method to determine the activities of additional materials in cement. Additional materials examined in this study were pozzolan from Lubuk Alung, pozzolan from Sicincin, and silica sand from Payakumbuh.

Pozzolan has a role in increasing the strength of mortar by forming calcium silicate $\left(\mathrm{CaSiO}_{3}\right)$ and calcium aluminate hydrate $\left(3 \mathrm{CaO} .2 \mathrm{SiO}_{2} .3 \mathrm{H}_{2} \mathrm{O}\right)$. Through the reaction between pozzolan, calcium hydroxide $/ \mathrm{Ca}(\mathrm{OH})_{2}$ in cement and water often results in long-term benefits including increased compressive strength. The increased compressive strength can be seen from the compressive strength test results.

Compressive strength test is a mechanical property of mortar which functions to see the effect of adding materials to the cement. The compressive strength of mortar is tested by making a mortar which will be pressed to shred. The compressive strength of mortar refers to the ASTM C109/C109M testing standard using $5 \times 5 \times 5 \mathrm{~cm}^{3}$ cube mold [9]. The test is carried out when the mortar is 28 days old in which the mortar is removed from the can stored in the oven at a temperature of $\mathrm{T}=38.0 \pm 2.00^{\circ} \mathrm{C}$ when the mortar is 27 days old. Before the testing, the mortar is also left until it reaches a temperature of $\mathrm{T}=23.0 \pm 2.00^{\circ} \mathrm{C}$. The compressive strength test is done using Hydr. Comp \& Bending Strength Machine until the maximum load is obtained. The test is conducted 3 times for each sample so that the average compressive strength is obtained.

\section{MATERIALS AND METHODS}

\subsection{Portland Cement}

Portland cement is hydraulic cement produced by smoothing clinker, especially from hydraulic calcium silicates (can harden if it reacts with water) with gypsum as the additional material [1012]. Cement contains $\mathrm{SiO}_{2}, \mathrm{CaO}, \mathrm{Al}_{2} \mathrm{O}_{3}$, and a small amount of $\mathrm{MgO}, \mathrm{Fe}_{2} \mathrm{O}_{3}$, and $\mathrm{SO}_{3}$. There are several types of cement, such as Portland Cement, White Cement, and Pozzolan Cement. Pozzolan contains $\mathrm{SiO}_{2}, \mathrm{Al}_{2} \mathrm{O}_{3}, \mathrm{MgO}, \mathrm{Fe}_{2} \mathrm{O}_{3}$, and $\mathrm{SO}_{3}$. The high content of $\mathrm{SiO}_{2}$ in pozzolan will react with $\mathrm{Ca}(\mathrm{OH})_{2}$ forming $\mathrm{CSH}$ which functions in cement hardening [13-16].

\subsection{Pozzolan}

Pozzolan is a material that contains silica and alumina and increases the strength of cement by forming calcium silicate and calcium aluminate hydrate from the reaction of pozzolan and 
calcium hydroxide in cement and water (ASTM C618-12) [17-18]. The quality requirements for pozzolan are shown in Table 1.

Table 1. Quality Requirements of Pozzolan Content of Compound Percentage

\begin{tabular}{cc}
\hline Content of Compound & Percentage \\
\hline $\mathrm{SiO}_{2}+\mathrm{Al}_{2} \mathrm{O}_{3}+\mathrm{Fe}_{2} \mathrm{O}_{3}$ & Minimum 70\% \\
$\mathrm{SO}_{3}$ & Minimum 4\% \\
Loss on Ignition & Minimum 10\% \\
Strength Activity Index & Minimum 75\% \\
\hline
\end{tabular}

\subsection{Silica Sand}

Silica sand is the raw material of cement which contains much silica oxide and alumina and acts as the additive and material to convert chemical composition shortage in the production of cement. The compounds contained in silica stones are $\pm 70 \% \mathrm{SiO}_{2}, \pm 13 \% \mathrm{Al}_{2} \mathrm{O}_{3}, \pm 16 \% \mathrm{Fe}_{2} \mathrm{O}_{3}$, and $\pm 1 \% \mathrm{CaO}[19-20]$.

\subsection{Strength Activity Index (SAI)}

Strength Activity Index (SAI) is a method to see the quality of additional materials mixed into cement which refers to the ASTM C595/C595M-12 standard [8]. The testing conducted in SAI is the Compressive Strength Test.

The comparison of the compressive strength of mortar with different variations can be calculated using the formula:

$$
f^{\prime} c=\frac{B}{A} x 102\left(\mathrm{~kg} / \mathrm{cm}^{2}\right)
$$

Which f'c is compressive strength of mortar $\left(\mathrm{kg} / \mathrm{cm}^{2}\right), \mathrm{B}$ is average load given $(\mathrm{kN})$ and $\mathrm{A}$ is area of loaded surface $\left(\mathrm{cm}^{2}\right)$

\subsection{Preparation of Samples}

The samples tested were pozzolan from Lubuk Alung, pozzolan from Sicincin, and silica sand from Payakumbuh. Ordinary Portland Cement (OPC) from PT. Semen Padang was added to the samples. There were two types of test objects in this study: the test materials without the addition of the third material (blank) and the test materials with the addition of the third material.

\section{A. Blank}

$250 \mathrm{~g}$ of Portland cement

$687.5 \mathrm{~g}$ of Ottawa sand

$\mathrm{X} \mathrm{ml}$ of water on the flow table (100 until 115) 
B. Test materials with the additional materials

$162.5 \mathrm{~g}$ of Portland cement

The mass of the third material:

$687.5 \mathrm{~g}$ of Ottawa sand

$$
87.5 \times \frac{\text { Bj of sample }}{\text { Bj of Portland cement }}
$$

$\mathrm{Y} \mathrm{ml}$ of water on the flow table (100 until 115)

\subsection{Storage of Samples}

After molded, samples that were still in the mold were placed in the curing chamber at a temperature of $\mathrm{T}=23.0 \pm 2.00^{\circ} \mathrm{C}$ for 24 hours. After that, the samples were removed from the mold and stored in an enclosed space which were protected from water droplets at a temperature of $\mathrm{T}=38.0 \pm 2.00^{\circ} \mathrm{C}$ for 27 days. Before the compressive strength test was carried out, the samples were cooled to a temperature of $\mathrm{T}=23.0 \pm 2.00^{\circ} \mathrm{C}$.

\subsection{Compressive Strength Test}

The compressive strength test refers to the ASTM C109/C109M method using equation 1 above [4]. The sample testing was carried out on samples that were 28 days old.

\subsection{Calculations}

The Activity Index with Portland cement can be calculated using equation 3 as follows.

$$
\text { A.I.W.P.C }=\frac{A}{B} \times 100
$$

Which $\mathrm{A}$ is average compressive strength test from blank $\left(\mathrm{kg} / \mathrm{cm}^{2}\right)$ and $\mathrm{B}$ is average compressive strength test from test objects with additional materials $\left(\mathrm{kg} / \mathrm{cm}^{2}\right)$

\section{RESULTS AND DISCUSSION}

\subsection{Results of Density}

Table 2 shows the results of the samples' density using the Gas Pycnometer. The density test is useful for calculating the mass of the third material which is mixed into Ordinary Portland Cement (OPC).

Table 2. Data of Density Test Results

\begin{tabular}{clcc}
\hline No & \multicolumn{1}{c}{ Material } & Mass $(\mathrm{g})$ & Density $\left(\mathrm{g} / \mathrm{cm}^{3}\right)$ \\
\hline 1. & Blank & 5.0873 & 3.1760 \\
2. & Pozzolan from Lubuk Alung & 5.9365 & 2.4633 \\
3. & Pozzolan from Sicincin & 5.1287 & 2.4954 \\
4. & Silica Sand & 5.6538 & 2.7003 \\
\hline
\end{tabular}


Based on the gas pycnometer results, the largest density was obtained by silica sand from Payakumbuh with $2.7003 \mathrm{~g} / \mathrm{cm}^{3}$. In contrast, the density results of pozzolan from Lubuk Alung and pozzolan from Sicincin were $2.4633 \mathrm{~g} / \mathrm{cm}^{3}$ and $2.4954 \mathrm{~g} / \mathrm{cm}^{3}$, respectively.

\subsection{Analysis of Complete Chemical Composition of the Third Material}

Based on the data collected from the laboratory, the supporting material for the usage analysis of pozzolan and silica sand on the X-Ray Fluorescence test (XRF) can be seen in Table 3. The chemical composition test was conducted because the increasing amount of total oxide of silica, aluminum, and iron present in the test samples might result in the higher activity of the pozzolan. The minimum total amount of $\mathrm{SiO}_{2}+\mathrm{Al}_{2} \mathrm{O}_{3}+\mathrm{Fe}_{2} \mathrm{O}_{3}$ of pozzolan is $>70 \%$. This percentage is in accordance with ASTM C 618-12. In terms of internal specifications of PT. Semen Padang, however, the total amount of $\mathrm{SiO}_{2}+\mathrm{Al}_{2} \mathrm{O}_{3}+\mathrm{Fe}_{2} \mathrm{O}_{3}$ is $\geq 80 \%$. Based on Table 3, all samples fulfilled the requirements according to ASTM C 618-12 and internal specifications of PT. Semen Padang. However, the X-Ray Fluorescence test (XRF) cannot be used as a benchmark to replace the pozzolan currently used by PT. Semen Padang because other factors might also influence the pozzolan activities.

Table 3. Data of Complete Chemical Composition Test Results

\begin{tabular}{ccccccccc}
\hline \multicolumn{10}{c}{ Test Results } \\
\hline $\begin{array}{c}\text { Name of } \\
\text { Materials }\end{array}$ & $\begin{array}{c}\mathrm{SiO}_{2}+\mathrm{Al}_{2} \mathrm{O}_{3}+ \\
\mathrm{Fe}_{2} \mathrm{O}_{3} \\
(\%)\end{array}$ & $\begin{array}{c}\mathrm{H}_{2} \mathrm{O} \\
(\%)\end{array}$ & $\begin{array}{c}\mathrm{SiO}_{2} \\
(\%)\end{array}$ & $\begin{array}{c}\mathrm{Al}_{2} \mathrm{O}_{3} \\
(\%)\end{array}$ & $\begin{array}{c}\mathrm{Fe}_{2} \mathrm{O}_{3} \\
(\%)\end{array}$ & $\begin{array}{c}\mathrm{CaO} \\
(\%)\end{array}$ & $\begin{array}{c}\mathrm{MgO} \\
(\%)\end{array}$ & $\begin{array}{c}\mathrm{LOI} \\
(\%)\end{array}$ \\
\hline $\begin{array}{c}\text { Pozzolan from } \\
\text { Lubuk Alung }\end{array}$ & 89.62 & 16.93 & 70.89 & 16.81 & 1.92 & 2.19 & 0.66 & 4.10 \\
Pozzolan from \\
$\begin{array}{c}\text { Sicincin } \\
\text { Silica Sand }\end{array}$ & 89.24 & 16.98 & 68.71 & 17.75 & 2.78 & 1.46 & 0.93 & 4.98 \\
\hline
\end{tabular}

\subsection{Results of the Compressive Strength Test}

The compressive strength test of mortar was tested at 28 days on $19^{\text {th }}$ January 2017 with treatments according to the ASTM C595/C595M-12 method [3]. Before the test, the samples that were still in the mold were stored at a temperature of $\mathrm{T}=23.0 \pm 2.00^{\circ} \mathrm{C}$ for a day. Then, the three samples were stored at a temperature of $\mathrm{T}=38.0 \pm 2.00^{\circ} \mathrm{C}$ for 27 days. Before the test was carried out, the samples were left until it reached the temperature of $\mathrm{T}=23.0 \pm 2.00^{\circ} \mathrm{C}$. The compressive strength test was done using Hydr. Comp \& Bending Strength Machine tool which can reach a compressive strength up to $300 \mathrm{kN}$.

The results of the compressive strength test of pozzolan and silica sand in the present study with OPC using the ASTM C595/C595-12 method is described in Table 4.

Table 4. Data of Compressive Strength Test Results 


\begin{tabular}{|c|c|c|c|c|}
\hline Name of Example & SAI of Blank & $\begin{array}{l}\text { SAI of Pozzolan } \\
\text { from Lubuk } \\
\text { Alung } \\
\end{array}$ & $\begin{array}{c}\text { SAI of } \\
\text { Pozzolan from } \\
\text { Sicincin } \\
\end{array}$ & $\begin{array}{l}\text { SAI of Silica } \\
\text { Sand from } \\
\text { Payakumbuh }\end{array}$ \\
\hline Area $\left(\mathrm{cm}^{2}\right) \quad(\mathrm{A})$ & 25 & 25 & 25 & 25 \\
\hline $\mathrm{kN}(1)$ & 86.3 & 81.9 & 71.3 & 48.2 \\
\hline $\mathrm{kN}(2)$ & 86.5 & 78.9 & 71.7 & 48.6 \\
\hline $\mathrm{kN}(3)$ & 90.3 & 79.7 & 74.9 & 49.2 \\
\hline Average (kN) (B) & 87.7 & 80.2 & 72.6 & 48.7 \\
\hline $\begin{array}{l}\text { Compressive Strength: } \\
\qquad \mathrm{B} \times \frac{102}{A}\left(\mathrm{~kg} / \mathrm{cm}^{2}\right)\end{array}$ & 358 & 327 & 296 & 199 \\
\hline AIWPC \% & & 91.34 & 82.68 & 55.58 \\
\hline
\end{tabular}

Based on the above data, the results of compressive strength were obtained on the treatment for 28 days using the ASTM C595/C595M-12 method with different additional materials [8]. The compressive strength of pozzolan from Lubuk Alung, pozzolan from Sicincin, and silica sand from Payakumbuh was $327 \mathrm{~kg} / \mathrm{cm}^{2}, 296 \mathrm{~kg} / \mathrm{cm}^{2}$, and $199 \mathrm{~kg} / \mathrm{cm}^{2}$, respectively. This means that pozzolan from Lubuk Alung has the largest compressive strength compared to other additional materials.

The Strength Activity Index (SAI) results can be one of the guidelines to determine the quality of the third material as shown in Figure 1.

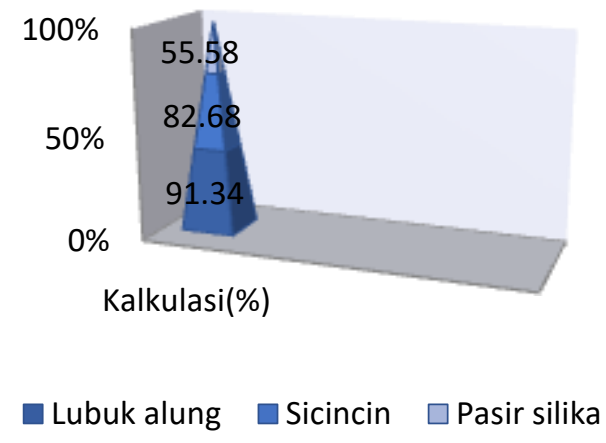

Figure 1. The Results of Activity Index with Portland Cement Using ASTM C595/C595-12 Method

According to ASTM C618-12 [17], the quality requirement for pozzolan shown in Table 1 is the SAI result should be a minimum of $75 \%$. Based on the data above, the materials which met the requirement of ASTM C618-12 [17] were pozzolan from Lubuk Alung and pozzolan from Sicincin with $91.3 \%$ and $82.68 \%$ respectively. In contrast, silica sand from Payakumbuh did not meet the requirement because the result was only $55.58 \%$.

\section{CONCLUSIONS}

Based on the study results, data analysis, and discussion, it can be concluded that: 
1. The 28-day compressive strength test values of the three additional materials mixed into the cement were as follows: pozzolan from Lubuk Alung was $327 \mathrm{~kg} / \mathrm{cm}^{2}$, pozzolan from Sicincin was $296 \mathrm{~kg} / \mathrm{cm}^{2}$, and silica sand from Payakumbuh was $199 \mathrm{~kg} / \mathrm{cm}^{2}$.

2. The Strength Activity Index (SAI) values that fulfilled the requirement of ASTM C618-12 were pozzolan from Lubuk Alung with $91.3 \%$ and pozzolan from Sicincin with $82.68 \%$. In contrast, silica sand from Payakumbuh did not fulfill the requirement because the value was only $55.58 \%$.

\section{REFERENCES}

[1] P. Fithri and A. Sindikia, "Pengendalian Persedian Pozzolan di PT. Semen Padang," Jurnal Optimasi Sistem Industri, vol. 13, no. 2, pp. 665-686, 2014.

[2] J. R. Pan, C. Huang, J-J. Kuo and S-H. Lin, "Recycling MSWI Bottom and Fly Ash as Raw Materials for Portland Cement," Waste Management, vol. 28, no. 7, pp. 1113-1118, 2008.

[3] T. R. Naik, "Sustainability of Concrete Construction," Practice Periodical on Structural Design and Construction, vol. 13, no. 2, pp. 98-103, 2008.

[4] M. Schneider, M. Romer, M. Tschudin and H. Bolio, "Sustainable Cement ProductionPresent and Future," Cement and Concrete Research, vol. 41, no. 7, pp. 642-650, 2011.

[5] H. Siagian and A. Dermawan, "Pengujian Sifat Mekanik Batako yang Dicampur Abu Terbang (Fly Ash)," Jurnal Sains Indonesia, vol. 35, no. 1, pp. 23-28, 2011.

[6] H. Jiang, Z. Qi, E. Yilmaz, J. Han, J. Qiu and C. Dong, "Effectiveness of Alkali-Activated Slag as Alternative Binder on Workability and Early Age Compressive Strength of Cemented Paste Backfills," Construction and Building Materials, vol. 218, pp. 689-700, 2019.

[7] A. Arulrajah, A. Mohammadinia, A. D'Amico and S. Horpibulsuk, "Cement Kiln Dust and Fly Ash Blends as An Alternative Binder for the Stabilization of Demolition Aggregates," Construction and Building Materials, vol. 145, pp. 218-225, 2017.

[8] ASTM C 595/C595M, Activity Index with Portland Cement. Annual Book of ASTM Standards, vol. 04, Philadelphia USA: American Society for Testing and materials, 2012.

[9] ASTM C 109/C109M, Compressive Strength Test for testing material. Annual Book of ASTM Standards, vol. 04, Philadelphia USA: American Society for Testing and materials, 1993.

[10] SNI 15-2049-2004, Semen Portland, Jakarta: Badan Standarisasi Nasional, 2004.

[11] T. C. Powers and T. L. Brownyard, (1946, September)"Studies of the Physical Properties of Hardened Portland Cement Paste," in Journal Proceedings International Concrete Abstracts Portal, vol. 43, no. 9, pp. 249-336, 1946.

[12] I. Islam, H. K. Chng and A. U. J. Yap, "Comparison of the Physical and Mechanical Properties of MTA and Portland Cement," Journal of Endodontics, vol. 32, no. 3, pp. 193197, 2006.

[13] S. H. Putero, W. Rosita, H. B. Santosa and R. Budiarto, "The Performance of Various Pozzolanic Material in Improving Quality of Strotium Liquid Waste Cemention," Procedia Environmental Sciences, vol. 17, pp. 703-710, 2013.

[14] R. Vedalakshmi, A. S. Raj, S. Srinivasan and K. G. Babu, "Quantification of Hydrated Cement Products of Blended Cements in Low and Medium Strength Concrete Using TG and DTA Technique," Thermochimica Acta, vol. 407, no. 1-2, pp. 49-60, 2003.

[15] K-L. Lin, B-Y. Chen, C-S. Chiou and A. Cheng, "Waste Brick's Potential for Use as A Pozzolan in Blended Portland Cement," Waste Management \& Research: The Journal for a Sustainable Circular Economy, vol. 28, no. 7, pp. 647-652, 2010.

[16] B. W. Jo, C. H. Kim and J. H. Lim, "Investigations on the Development of Powder Concrete with Nano-SiO ${ }_{2}$ Particles," KSCE Journal of Civil Engineering, vol. 11, no. 1, pp. 
37-42, 2007.

[17] ASTM C 618-94a, Standard Specification for Fly Ash and Raw Calcined Natural Pozzolan for Use as a Mineral Admixture in Portland Cement Concrete. Annual Book of ASTM Standards, vol. 04, Philadelphia USA: American Society for Testing and materials, 1993.

[18] M. Mouli and H. Khelafi, "Performance Characteristics of Lightweight Aggregate Concrete Containing Natural Pozzolan," Building and Environment, vol. 43, no. 1, pp. 31-36, 2008.

[19] Roekmini, Pengertian Umum Semen, Padang: Departemen Penelitian dan Pengembangan. PT. Semen Padang, 1998.

[20] P. Cardiano, R. C. Ponterio, S. Sergi, S. L. Schiavo and P. Piraino, "Epoxy-Silica Polymers as Stone Conservation Materials," Polymer, vol. 46, no.6, pp. 1857-1864, 2005. 